\title{
Feret coefficients for white self-compacting concrete
}

\author{
E. Júlio $\cdot$ N. Dias $\cdot$ J. Lourenço $\cdot$ J. Silva
}

Received: 25 February 2005 / Accepted: 20 July 2005

(C) RILEM 2006

\begin{abstract}
Several tests on white mortar, microconcrete, concrete and self-compacting concrete, considering different additions and admixtures, were conducted to characterize white cement and determine the corresponding Feret coefficients.

It was concluded that: (1) it is possible to make different mixtures of white self-compacting concrete (WSCC) with the materials adopted; (2) the method suggested by the JSCE is the one that better adapts to the studied WSCC mixtures; (3) the obtained values for the Feret coefficients can help the concrete designer predicting the compressive strength of the WSCC; (4) the Feret coefficients for WSCC are different from those for regular, white or gray, concrete.1359-5997 (C)2005 RILEM. All rights reserved.
\end{abstract}

Résumé Plusieurs testes en mortier, micro béton, béton et béton auto compactable blanc, considérant des différents additions et adjuvants, ont été conduits

\footnotetext{
E. Júlio

Department of Civil Engineering, University of Coimbra, Portugal (ejulio@dec.uc.pt)

N. Dias

Sika Portugal, S.A.

J. Lourenço

I.S.E.C., Coimbra, Portugal

J. Silva

University of Coimbra, Portugal
}

pour caractériser le ciment blanc et déterminer les correspondants coefficients de Feret.

On a conclu que: (1) il est possible de produire des différents compositions de béton auto compactable blanc (WSCC) avec les matériaux adoptés; (2) la méthode suggérée para la JSCE est celle qui mieux s'adapte aux compositions de WSCC étudiées; (3) les valeurs obtenus pour les coefficients de Feret peuvent aider à prédire la résistance à la compression $d u$ WSCC; (4) les coefficients de Feret pour WSCC sont différents de ceux pour bétons, blanc ou gris, courants.

\section{Introduction}

Based on the Faury method [1] and on the Feret expression [2], Lourenço [3] developed a method to predict the strength of regular concretes, i.e., gray, normal weight, normal consistency and normal strength concretes. During years, concrete mixtures, with different types of cement and different types and quantities of additions, were designed and tested to determine the corresponding Feret coefficients. This method has been used, with success, to design concrete mixtures to be applied in cast-in-place reinforced concrete structures, mainly buildings but also bridges, as well as in precast reinforced concrete elements.

White concrete has been used, in the past, basically on non-structural precast elements. Recently, some requests have been addressed, essentially to the precast industry, in order to produce white reinforced concrete 
elements with special architectonic requirements. Therefore, although the production of white concrete is a known process, some aspects must be taken into account in the mixture design of structural elements.

Self-compacting concrete (SCC) was first developed in Japan with the objective of achieving high durability concrete structures, independently of workmanship quality [4]. SCC presents major advantages, in relation to regular concrete, that contribute to achieve better quality concrete structures: better finish surfaces; and no need for vibration [5]. The consequent savings of manpower and equipment represent a significant economical advantage and the reduction of noise plays a key role, especially for precast industries, since it leads to better labour conditions.

White concrete, designed with SCC technology, would allow the production of precast, as well as on site, structural elements of higher quality with special aesthetic demands, fulfilling all the requirements previously mentioned. However, in order to predict the compressive strength of white self-compacting concrete (WSCC) it would be necessary to determine, first, the Feret coefficients for this new material. This has been defined, therefore, as the main objective of the study described in this article.

\section{Previous studies}

\subsection{The feret expression}

The expression of Feret relates empirically the compressive strength of a concrete with its compactness and dosage and type of cement [2]:

$f_{c, j}=K_{1, j} \times \gamma^{2}$

where $f_{c, j}$ is the value of the compressive strength, in $M P a, j$ days after the mixture; $K_{1, j}$ is the Feret coefficient, associated to the binder characteristics, $j$ days after the mixture; and $\gamma$ is the compactness of the binder paste, while fresh, given by:

$\gamma=\frac{v}{v+I}$

being $v$, the absolute volume of the binder components; and $I$, the voids index.

Re- writing expression (1) as follows:

$K_{1, j}=\frac{f_{c, j}}{\gamma^{2}}$

it is possible to determine values that correlate the percentages of cement and additions, for a given binder, with the compressive strength of the concrete [6].

\subsection{Feret coefficients for regular concrete}

Lourenço $[3,6]$ tested several concrete mixtures, with different types of cement, II 32.5, I 32.5, and I 42.5, with quantities, varying from $5 \%$ to $30 \%$, of different types of additions, fly ash and silica fume, and determined the corresponding Feret coefficients. In Table 1,

Table 1 Feret coefficients for regular gray concrete [3, 6]

\begin{tabular}{|c|c|c|c|c|c|c|c|}
\hline \multicolumn{4}{|l|}{ Type of cement } & \multicolumn{4}{|l|}{ I 42.5} \\
\hline Type of addition & & & & fly ash & & & \\
\hline Percentage of addition & $0 \%$ & $5 \%$ & $10 \%$ & $15 \%$ & $20 \%$ & $25 \%$ & $30 \%$ \\
\hline $\begin{array}{l}\mathrm{K}_{1,7} \text { (parameter assigned to the } \\
\text { strength after } 7 \text { days) }\end{array}$ & 265 to 300 & 240 to 260 & 235 to 250 & 225 to 245 & 215 to 235 & 205 to 225 & 195 to 215 \\
\hline $\begin{array}{l}\mathrm{K}_{1,28} \text { (parameter assigned to the } \\
\text { strength after } 28 \text { days) }\end{array}$ & 315 to 350 & 300 to 320 & 290 to 310 & 285 to 305 & 275 to 295 & 265 to 285 & 255 to 275 \\
\hline Type of cement & & & & I 42.5 & & & \\
\hline Type of addition & & & & silica fume & & & \\
\hline Percentage of addition & $0 \%$ & $5 \%$ & $10 \%$ & $15 \%$ & $20 \%$ & $25 \%$ & $30 \%$ \\
\hline $\begin{array}{l}\mathrm{K}_{1,7} \text { (parameter assigned to the } \\
\text { strength after } 7 \text { days) }\end{array}$ & 265 to 300 & 290 to 310 & 285 to 300 & 275 to 295 & 265 to 285 & 255 to 275 & 245 to 265 \\
\hline $\begin{array}{l}\mathrm{K}_{1,28} \text { (parameter assigned to the } \\
\text { strength after } 28 \text { days) }\end{array}$ & 315 to 350 & 340 to 360 & 330 to 350 & 320 to 340 & 315 to 330 & 305 to 325 & 295 to 315 \\
\hline
\end{tabular}


Table 2 White cement BR I 42.5 and additions

\begin{tabular}{|c|c|c|}
\hline \multicolumn{2}{|l|}{ Loss on ignition (P.F. \%) } & 2.8 \\
\hline \multicolumn{2}{|l|}{ Insoluble residuum (R.I. \%) } & 0.11 \\
\hline \multicolumn{2}{|l|}{ Density $\left(\mathrm{g} / \mathrm{m}^{3}\right)$} & 3.05 \\
\hline \multicolumn{2}{|l|}{ Index reflectance - Whiteness } & 85.11 \\
\hline \multicolumn{2}{|l|}{ Average particle diameter $(\mu \mathrm{m})$} & 11.4 \\
\hline \multicolumn{2}{|l|}{ Specific surface- Blaine $\left(\mathrm{cm}^{2} / \mathrm{g}\right)$} & 4400 \\
\hline \multicolumn{3}{|l|}{ Air setting times (min.): } \\
\hline \multicolumn{2}{|l|}{ Initial } & 95 \\
\hline \multicolumn{2}{|l|}{ Final } & 165 \\
\hline \multicolumn{3}{|l|}{ Compressive strength (MPa) } \\
\hline \multicolumn{2}{|l|}{1} & 20.0 \\
\hline \multicolumn{2}{|l|}{7} & 54.5 \\
\hline \multirow[t]{2}{*}{28} & & 69.1 \\
\hline & Limestone filler & Silica fume \\
\hline Loss on ignition (P.F. \%) & 43.1 & 6.0 \\
\hline Average Particle diameter $(\mu \mathrm{m})$ & 45 & 15 \\
\hline Density $\left(\mathrm{g} / \mathrm{m}^{3}\right)$ & 2.70 & 2.20 \\
\hline $\mathrm{CaCO}_{3}(\%)$ & 99.0 & - \\
\hline $\mathrm{SiO}_{2}(\%)$ & - & 98.0 \\
\hline Specific surface- Blaine $\left(\mathrm{cm}^{2} / \mathrm{g}\right)$ & 5150 & - \\
\hline Specific surface- BET $\left(\mathrm{m}^{2} / \mathrm{g}\right)$ & - & 50 \\
\hline Insoluble residuum in $\mathrm{HCl}(\%)$ & 0.36 & - \\
\hline
\end{tabular}

the Feret coefficients, obtained for cement type I 42.5, are presented $[3,6]$.

\section{Experimental program}

\subsection{Materials}

The materials used in this investigation were a Portland cement type BR I 42.5 (Table 2); two additions-a limestone filler and a white silica fume (Table 2); three limestone crushed aggregates and two natural siliceous sands (Table 3); and a polycarboxylate type superplasticizer (Table 3).

\subsection{White mortar, micro-concrete and concrete}

The first tests were performed with the three mixtures presented in Table 4: a standard mortar to test cements; and a micro concrete and a concrete mixtures, both defined using the Faury method [1]. The results of the tests are presented in Table 5.

After obtaining the compressive strength for each mixture, the Feret coefficients for 1, 7 and 28 days were calculated. These results are presented in Fig. 1.

The following conclusions, related to the Feret coefficients, can be drawn:

1. $K_{1, j}$ increases with time. This is because the compressive strength increases with time for the same mixture (same $\gamma$ );

2. $K_{1,7}$ and $K_{1,28}$ decrease when concrete replaces mortar. The justification for this result is based on the fact that the compressive strength depends on the relation between the mortar and the coarse aggregates. With the increase of the maximum size of the coarse aggregates, the heterogeneity of the internal stress state is also increased. Furthermore, the coarse aggregates used have low mechanical characteristics. For these reasons, when concrete replaces mortar, $K_{1, j}$ decreases;

3. $K_{1,1}$ are similar because low compressive strength values were reached, being the differences between the three mixtures not noticed.

Table 3 Aggregates and admixture

\begin{tabular}{llllll}
\hline & $\begin{array}{l}\text { Coarse } \\
\text { aggreg. B2 }\end{array}$ & $\begin{array}{l}\text { Coarse } \\
\text { aggreg. B1 }\end{array}$ & $\begin{array}{l}\text { Coarse } \\
\text { aggreg. BA }\end{array}$ & $\begin{array}{l}\text { Fine aggreg. } \\
\text { Sand AG }\end{array}$ & $\begin{array}{l}\text { Fine aggreg. } \\
\text { Sand AF }\end{array}$ \\
\hline Fineness modulus & 6.89 & 6.07 & 5.20 & 2.57 & 1.07 \\
Specific weight $\left(\mathrm{kg} / \mathrm{dm}^{3}\right)$ & 2.69 & 2.69 & 2.69 & 2.64 & 2.60 \\
Water absorpt. $(\%)$ & 0.8 & 0.9 & 1.7 & 0.5 & 1.0 \\
Type & & & & & $\begin{array}{c}\text { Polycarboxylate type } \\
\text { superplasticizer }\end{array}$ \\
& & & & & $1.05 \pm 0.02$ \\
Density $\left(\mathrm{g} / \mathrm{m}^{3}\right)$ & & & & $5.0 \pm 1.0$ \\
Solid content $(\%)$ & & & & Yellowish \\
pH & & & & & \\
Color & & & & & \\
\hline
\end{tabular}


Table 4 White mortar, micro-concrete and concrete mixtures

\begin{tabular}{llll}
\hline Constituents $\left(\mathrm{kg} / \mathrm{m}^{3}\right)$ & Mortar & Micro-Concrete & Concrete \\
\hline Cement & 500 & 450 & 400 \\
Water & 250 & 250 & 186 \\
Reference sand CEN & 1500 & - & - \\
Coarse aggregate B2 & - & - & 632 \\
Coarse aggregate B1 & - & - & 115 \\
Coarse aggregate BA & - & 999 & 409 \\
Fine aggreg. - Sand AG & - & 477 & 499 \\
Fine aggreg.-Sand AF & - & 144 & 114 \\
\hline
\end{tabular}

Table 5 Results for white mortar, micro-concrete and concrete

\begin{tabular}{|c|c|c|c|}
\hline & Mortar & $\begin{array}{l}\text { Micro } \\
\text { Concrete }\end{array}$ & Concrete \\
\hline Flow table for mortar (mm) & 182 & - & - \\
\hline Slump_Abrams cone (mm) & - & 123 & 115 \\
\hline Flow table for concrete (mm) & - & 520 & 500 \\
\hline Air content $(\%)$ & 4.2 & 3.0 & 2.0 \\
\hline \multicolumn{4}{|l|}{ Compressive strength (MPa) } \\
\hline 1 day & 20.0 & 22.4 & 23.2 \\
\hline 7 days & 54.5 & 43.2 & 43.6 \\
\hline 28 days & 69.1 & 54.7 & 51.5 \\
\hline
\end{tabular}

\subsection{White concrete with different additions and} admixtures

These tests were performed with mixtures obtained from the first concrete mixture by varying the binder, introducing two additions and an admixture. All the mixtures, shown in Table 6, were defined using the Faury method. The tests results are presented in Table 7. With the compressive strength of each mixture, the Feret coefficients were calculated for 1,7 and 28 days and are given in Figs. 2 and 3.

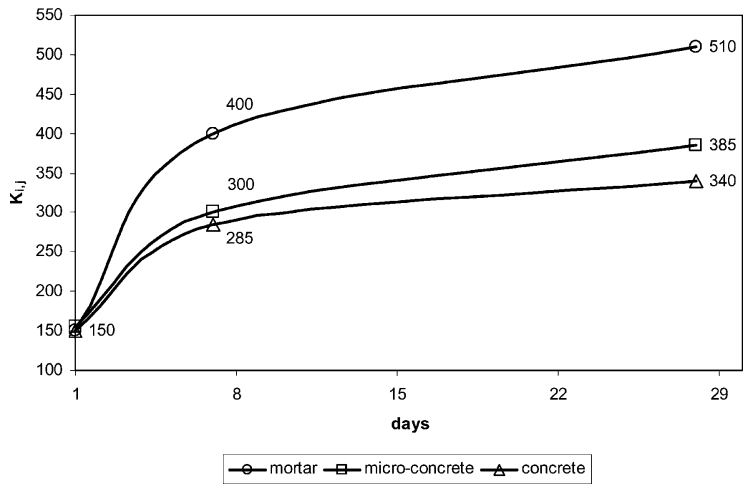

Fig. 1 Feret coefficients for white mortar, micro-concrete and concrete.

Analyzing the results of the Feret coefficients, it is possible to conclude that:

1. $K_{1, j}$ increases with time;

2. $K_{1, j}$ decreases when, in a mixture where the binder is cement, $5 \%$ c.w. (in cement weight) of limestone filler is added. Again, the same happens when $20 \%$ c.w. of limestone filler is added. This result is due to the fact that this filler has no pozzolanic properties and the water-cement ratio is increased;

3. $K_{1, j}$ increases when, in a mixture where the binder is cement, $5 \%$ c.w. of silica fume is added. This result is due to the fact that this filler has pozzolanic properties;

4. $K_{1,1}$ increases when an admixture is added. The reason for this fact is that, when the admixture is used as a water reducer (since it leads to a better dispersion of the cement particles), it decreases the water/binder ratio, resulting on a higher compactness. Moreover, it also increases the velocity of the clinkers reactions with water, as a consequence of a bigger

Table 6 White concrete mixtures with and without admixtures and additions

\begin{tabular}{|c|c|c|c|c|c|c|c|}
\hline Constituents $(\mathrm{kg} / \mathrm{m} 3)$ & $c+5 \%$ filler & $c+20 \%$ filler & $c+5 \%$ silica & $\mathrm{c}$ & $c+5 \%$ filler & $c+20 \%$ filler & $c+5 \%$ silica \\
\hline Cement & 400 & 400 & 400 & 400 & 400 & 400 & 400 \\
\hline Limestone filler & 20 & 80 & - & - & 20 & 80 & - \\
\hline Silica fume & - & - & 20 & - & - & - & 20 \\
\hline Admixture & - & - & - & 3.6 & 3.6 & 3.6 & 3.6 \\
\hline Water & 190 & 196 & 225 & 154 & 157 & 161 & 189 \\
\hline Coarse aggreg. B2 & 629 & 624 & 601 & 655 & 653 & 650 & 627 \\
\hline Coarse aggreg. B1 & 115 & 114 & 110 & 119 & 119 & 119 & 114 \\
\hline Coarse aggreg. BA & 406 & 401 & 387 & 425 & 422 & 418 & 405 \\
\hline Fine aggregate -Sand AG & 501 & 507 & 482 & 515 & 517 & 525 & 500 \\
\hline Fine aggregate -Sand AF & 90 & 21 & 62 & 133 & 109 & 40 & 83 \\
\hline
\end{tabular}


Table 7 Results for white concrete mixtures with and without admixtures and additions

\begin{tabular}{llllllll}
\hline & $c+5 \%$ filler & $c+20 \%$ filler & $c+5 \%$ silica & $c$ & $c+5 \%$ filler & $c+20 \%$ filler & $c+5 \%$ silica \\
\hline Slump-Abrams cone (mm) & 117 & 122 & 115 & 128 & 137 & 143 & 120 \\
Flow table for concrete (mm) & 495 & 500 & 493 & 428 & 435 & 440 & 425 \\
Air content (\%) & 2.0 & 2.0 & 1.9 & - & - & - & - \\
Compressive strength (MPa) & & & & & & & \\
$\quad$ 1 day & 22.4 & 24.3 & 20.6 & 34.8 & 34.1 & 36.2 & 29.8 \\
$\quad 7$ days & 43.1 & 42.6 & 39.2 & 52.3 & 51.9 & 51.4 & 45.7 \\
$\quad 28$ days & 49.8 & 52.4 & 47.9 & 59.2 & 59.0 & 58.0 & 53.6 \\
\hline
\end{tabular}

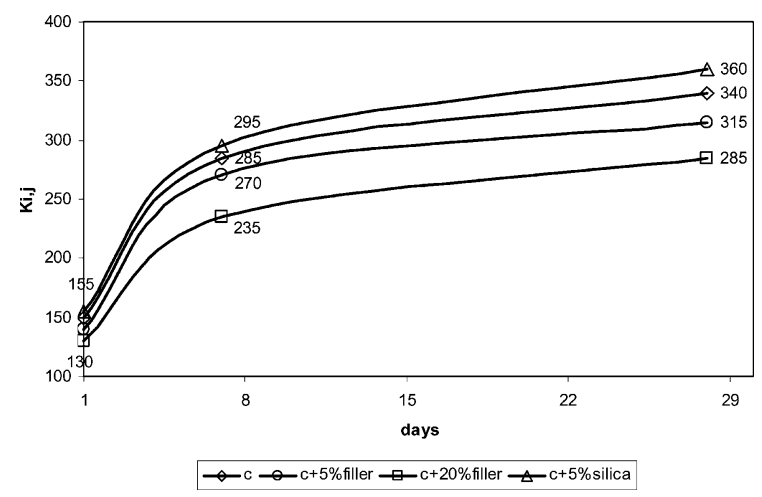

Fig. 2 Feret coefficients for white concrete without admixture.

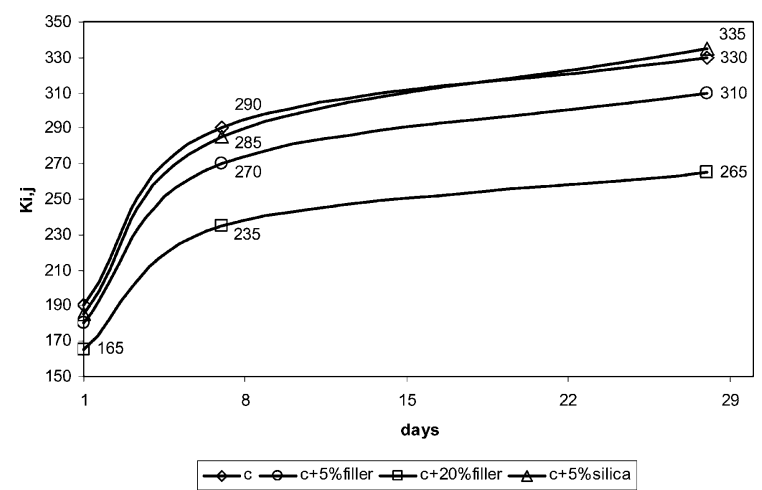

Fig. 3 Feret coefficients for white concrete with admixture.

concentration of the reagents in the mixture, resulting in a faster increase of compressive strength;

5. The Feret coefficients obtained for white concrete are similar to those determined by Lourenço $[3,6]$ for gray concrete.

\subsection{White self-compacting concrete (WSCC)}

The WSCC mixtures considered are presented in Table 8 . These mixtures were defined using the methods recommended by Okamura et al. $[4,7,8]$ and by the
Table 8 WSCC mixtures

\begin{tabular}{llccc}
\hline & \multicolumn{5}{c}{$\mathrm{c}+5 \%$} & $\mathrm{c}+20 \%$ & $\mathrm{c}+5 \%$ \\
Constituents $\left(\mathrm{kg} / \mathrm{m}^{3}\right)$ & $\mathrm{c}$ & filler & filler & silica \\
\hline Cement & 500 & 476 & 416 & 476 \\
Limestone filler & - & 24 & 84 & - \\
Silica fume & - & - & - & 24 \\
Admixture & 8.9 & 8.5 & 7.4 & 12.5 \\
Water & 155 & 158 & 161 & 175 \\
Coarse aggregate B1 & 800 & 800 & 800 & 800 \\
Coarse aggregate BA & 100 & 100 & 95 & 76 \\
Fine aggregate-Sand AG & 400 & 395 & 390 & 375 \\
Fine aggregate-Sand AF & 400 & 395 & 390 & 375 \\
& & & &
\end{tabular}

Japan Society for Civil Engineers [7, 9]. To test and classify the fresh concrete, namely to assess the ability to flow of the WSCC, several tests were used [10]: the slump flow test, the European L Box test, the V funnel test and the modified settlement column test.

The slump flow test evaluates the flow capacity of the SCC, by measuring the speed of the flow and the final spread (Fig.4), under its own weight [9]. This is one of the most used tests to evaluate the consistency of a SCC. It has the advantage of providing a good assessment of the filling ability of the concrete and it can be performed in laboratory as well as on site. There is no specific worldwide assumption in relation to the reasonable value for the final spread of concrete. Several suggestions are available, based on different experiences [11-13]. The results for the four mixtures were very similar and are shown in Table 9.

With the European L-Box [14] test it is also possible to evaluate properties such as the filling ability, blocking and segregation. The test consists on filling the vertical section with concrete; lifting the gate; and allowing the concrete flow through the horizontal section (Fig. 4). The time needed for the concrete to reach 
Table 9 Test results for WSCC

\begin{tabular}{|c|c|c|c|c|}
\hline & $\mathrm{c}$ & $\begin{array}{c}c+5 \% \\
\text { filler }\end{array}$ & $\begin{array}{c}c+20 \% \\
\quad \text { filler }\end{array}$ & $\begin{array}{c}c+5 \% \\
\text { silica }\end{array}$ \\
\hline Slump flow spread (mm) & 720 & 700 & 690 & 710 \\
\hline \multicolumn{5}{|c|}{ Compressive strength (MPa) } \\
\hline 1 days & 46.7 & 43.9 & 42.7 & 42.0 \\
\hline 7 days & 54.7 & 51.1 & 50.0 & 57.9 \\
\hline 28 days & 72.6 & 70.3 & 66.9 & 81.4 \\
\hline
\end{tabular}
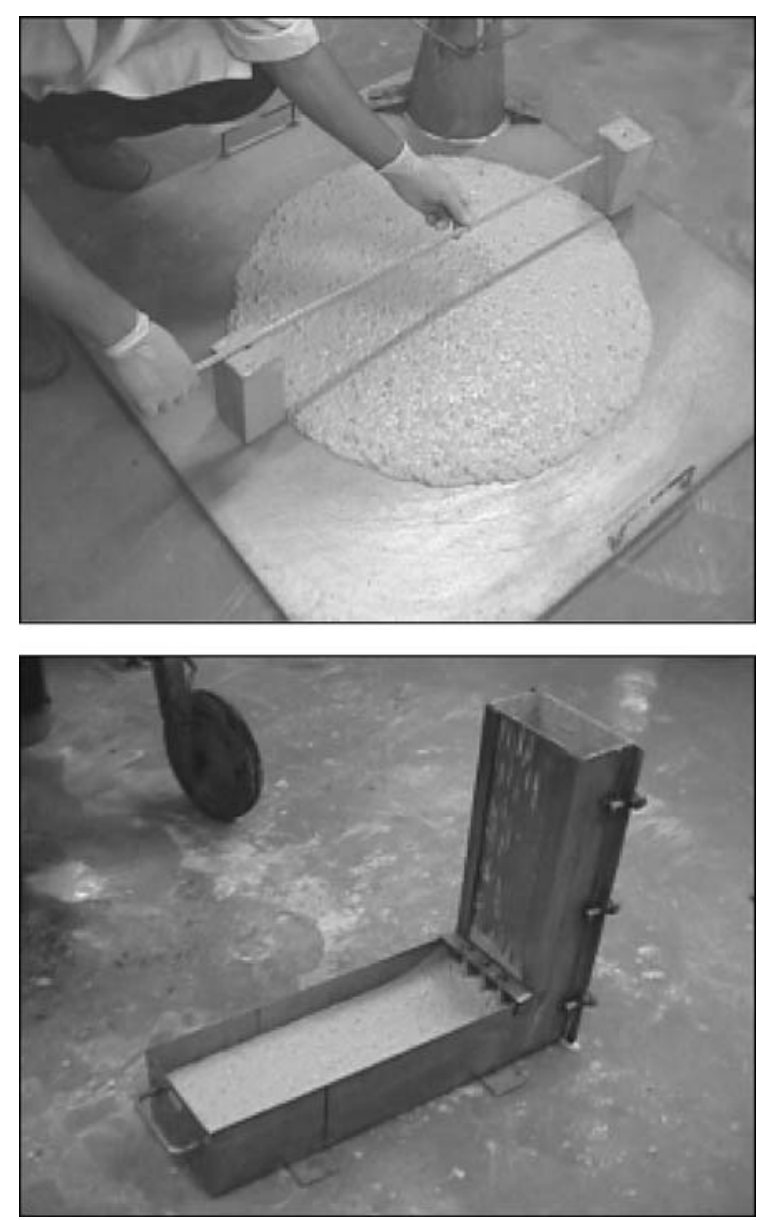

Fig. 4 Slump flow spread and European L-Box.

a distance of $200 \mathrm{~mm}, 400 \mathrm{~mm}$ and to stop is recorded and the height of the concrete at the end of the box $(\mathrm{H} 2)$ and at the beginning (H1) is measured and expressed as the blocking effect $=\mathrm{H} 2 / \mathrm{H} 1$. Values varying from 0.80 to 0.85 are suggested for the blocking effect [11]. The measured value was 0.90 .

The V-funnel test [15] consists on measuring the time the concrete takes to flow through a narrow open- ing until a light is seen from above and through the funnel-flow time. With this test it is also possible to evaluate the resistance to segregation. Some researchers suggest for the flow time values between 4 and $10 \mathrm{~s}$ [14], and others values between 7 and $11 \mathrm{~s}$ [4]. The result for the flow time was of $10 \mathrm{~s}$.

The objective of the settlement column test [15] is to quantitatively assess the capacity of a SCC to resist to segregation. The test consists on filling the column; striking the mortar table and taking samples from the top and the bottom doors. These samples must be washed out and dried before their mass is determined. The ratio between the values obtained from the top and the bottom samples is proportional to the capacity of the concrete to resist to segregation. Rooney and Bartos [15] suggested that values between 0.782 and 1.048 would be acceptable. The result for the Settlement column test was 0.95 .

The compressive strength of the hardened WSCC was also determined and the results can be seen in Table 9. After obtaining the compressive strength for each mixture the Feret coefficients were calculated for 1, 7 and 28 days. These results can be observed in Fig. 5 .

It is possible to take the same conclusions over the Feret coefficients for the WSCC that have been taken for the regular concrete mixtures:

1. $K_{1, j}$ increases with time;

2. $K_{1, j}$ decreases when, in a mixture where the binder is cement, $5 \%$ c.w. of limestone filler is added. Again, the same happens when $20 \%$ c.w. of limestone filler is added;

3. $K_{1, j}$ increases when, in a mixture where the binder is cement, $5 \%$ c.w. of silica fume is added; being the pozzolanic effect of the filler much more significant

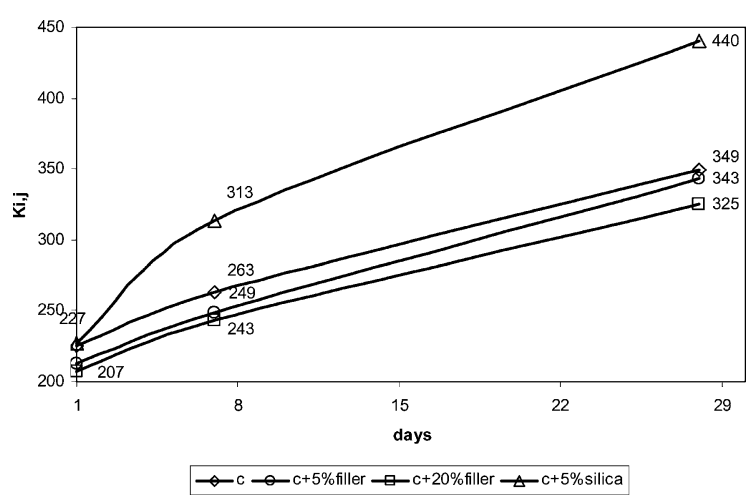

Fig. 5 Feret coefficients for WSCC. 
in this case than in the case of regular white concrete, previously presented;

4. $K_{1,1}$ increases when an admixture is added; the velocity increase of the clinkers reactions with water is also much more important in this case than in the case of regular white concrete.

\section{Conclusions and future developments}

\subsection{Conclusions}

It is possible to design different mixtures of WSCC with the materials adopted.

The method suggested by the Japan Society of Civil Engineers is the one that better adapts to the studied mixtures.

The obtained values of the Feret coefficients can help concrete designers predict the compressive strength of WSCC.

The Feret coefficients for WSCC are different from those for regular, white or gray, concrete.

\subsection{Future developments}

It would be interesting to modify the Faury method in order to obtain better results with SCC.

Further tests should be conducted to explain the observed different influence of white silica fume on regular, white and gray, concrete and on WSCC.

\section{References}

1. Faury J (1958) Le béton, 3.ème edition, Dunod Paris.

2. Lourenço JF (1995) Around Feret expression (only available in Portuguese)-ISEC.

3. Lourenço JF (1995) Concrete design (only available in Portuguese), ISEC.
4. Okamura H, Ouchi M, (1999) Self-compacting concrete. Development, present use and future, Proceedings of the first International RILEM Symposium-Stockholm, Edited by A. Skarendahl and O. Petersson, Stockholm, Sweden, 3-14.

5. Dias N (2002) White Self-Compacting Concrete (only available in Portuguese), MSc thesis, University of Coimbra.

6. Lourenço J, Júlio E, Maranha P (2004) Light weight aggregates concrete. User Guide (only available in Portuguese), APEB.

7. Domone P (2001) Mix design, self-compacting concrete. State-of-the-Art report of RILEM Technical Committee 174SCC. Edited by A. Skarendahl and O. Petersson, France 4965.

8. Okamura H, Ozawa K, Ouchi M (2000) Self-compacting concrete, Structural Concrete, N 1:3-17.

9. Recommendation for Self-Compacting Concrete. Concrete Engineering Series 31, Japan Society of Civil Engineers, Edited by Taketo Uomoto, Kazumasa Ozawa, Tokyo August 1999.

10. Dias N, Júlio ES, Lourenço JF, Silva JM (2003) Design and characterization of white Self-compacting concrete. XXXI IAHS World Congress Montreal Canada, 23-27.

11. David J (1999) Self-compacting concrete: a new material for precast industry" (only available in Portuguese), Terceiras Jornadas de Estruturas de Betão. Faculdade de Engenharia da Universidade do Porto Porto, 97-110,.

12. Takada K (2001) Placement, self-compacting concretestate-of-the-art report of RILEM Technical Committee 174SCC, Edited by A. Skarendahl and O Petersson France 7987.

13. Bui VK, Montgomery D (1999) Mixture proportioning method for self-compacting high performance concrete with minimum paste volume, Proceedings of the first International RILEM Symposium, Edited by A. Skarendahl and O Petersson Stockholm Sweden 373-384.

14. "Self-Compacting Concrete-State-of-the-Art report of RILEM Technical Committee 174-SCC. RILEM Report 23, Edited by A. Skarendahl and O. Petersson, RILEM Publications S.A.R.L., France 2001.

15. Takada K (2001) V-funnel test, Self-Compacting Concrete - State-of-the-Art report of RILEM Technical Committee 174-SCC, Edited by A. Skarendahl and O. Petersson France 120-122.

16. Rooney MJ, Bartos JM (2001) Development of the settlement column segregation test for fresh self-compacting concrete. Proceedings of the second International Symposium on Self-Compacting Concrete, Edited by Kazumasa Ozawa \& Masahiro Ouchi Tokyo 109-116,. 